\title{
周波数成分からみた示指伸筋の疲労について
}

\author{
寺 沢 宏 次 ${ }^{*}$ 藤 原 孝 之** 柳 沢 健*** \\ 酒 井秋 男**** 上 田 五 雨****
}

\section{EMG ANALYSIS OF MUSCLE FATIGUE DURING ISOMETRIC CONTRACTION OF THE INDICIS PROPRIUS}

\author{
Koji Terasawa, Takayuki Fujiwara, Ken Yanagisawa, \\ Akio Sakai and Gou Ueda
}

\begin{abstract}
A study was conducted to investigate muscle fatigue during isometric contraction of the indicis proprius using EMG analysis (BIMUTAS Ver. 2. 1).

The subjects were 8 healthy men (ranging in age from 19 to 42 years).

Plummets (ranging from $300 \mathrm{~g}$ to $600 \mathrm{~g}$ ) were placed on the distal knuckle of the index finger to create loads on the indicis proprius muscle. EMG was recorded until the plummet dropped, and the total time required was divided into 10 equal parts. In each part, the EMG record for the first $1000 \mathrm{~ms}$ was picked out. Then the mean power frequency (MePF) and median power frequency (MdPF) of the power spectrum were calculated.

The results were as follows:

1) Both MePF and MdPF showed shifs to lower frequency bands.

2) Integrated values of the EMG power spectrum increased with time.

3) The time courses of the MePF and MdPF in each EMG sample for the 8 subjects were determined by the 3 -point moving average method.

A break-point was observed in each MePF and MdPF diagram.

It was considered that two-break points observed in the time courses of the EMG record were valid as an objective index of local muscle fatigue.
\end{abstract}

(Jpn. J. Phys. Fitness Sports Med. 1992, $41: 108 \sim 116$ )

key words : Electromyogram, Fatigue, Median power frequency

\section{I.はじめに}

笳力トレーニングは強度, 時間, 頻度と三つの 条件を満たすことによって, 笳線維が肥大し, 最 大筋力が増大するといわれている8 . この筋力ト レーニングの時間的経過のなかで笳力増加は, 筋 の形態学的変化以上に早くみられ, 運動学習が筋
力発揮時に影響をおよぼすものと考少られてい る $^{2)}$.また，筋力の増加は，それに伴ら筋の運動 単位放電の增加と笳収縮組織の形態学的变化の要 素が関与し，いわゆる神経的要素の改善によって もたらされているのではないかといらことが指摘

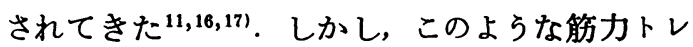
ーニングを極限まで行うと筋肉は疲労し，翌日，
*信州大学教盖部

干390 長野韶松本市旭3-1-1

**信州大学医療技術短期大学

干390 長野県松本市旭3-1-1

***東京都立医療技術短期大学

干116 東京都荒川区東尾久7-2-10

****信州大学医学部環境生理学教室

干390 長野県松本市旭3-1-1
Faculty of Liberal Arts, Shinshu University 3-1-1 Asahi, Matsumoto 390, Japan

School of Allied Medical Sciences, Shinshu University 3-1-1 Asahi, Matsumoto 390, Japan

School of Allied Medical Sciences, Tokyo Metropolitan College 7-2-10

Higashiogu, Arakawa-ku, Tokyo 116, Japan

Department of Environmental Physiology, Shinshu University

School of Medicine 3-1-1 Asahi, Matsumoto 390, Japan 
あるいは数日後までその影響が残る場合がある。 この筋疲労は，䇗収縮を継続することによって生 じるすのとされているが，たとえば筋の随意収縮 が円滑に行われなくなり，大きな筋力を発生する ことができなくなった場合，筋疲労が進行してい るものと考えられる ${ }^{201}$. この筋疲労が生体内でど のように起こり，変化しているのかをみる客観的 指標としては，筋収縮を電気的活動として捉える むのと, 筋の生理的 ·生化学的適応として捉光る ものとが考えられる. 筋収縮を電気的に捉えるも のとしては, Piper ${ }^{26)}$ が1912年に筋電図のモノグ ラフを発表して以来, 研究が進み筋収縮のメカニ ズムが解明されていき3,91, 針電極からの筋電位の 導出も行われるよらになってきた 図の臨床への応用から試みられるよらになり ${ }^{34)}$, 表面筋電位導出方法も開発されていき5,23,35), 筋 電図の 積分処理, 周波数分析, (パワースペクト ル),がなされるよらになってきた 22,24,28).この ような分析が進むにつれて筋疲労の定義として現 在では，次の三つが提唱されている.すなわち,

(1) 最大筋張力発生の減少

(2) 一定張力保持中に EMG 活動の増加

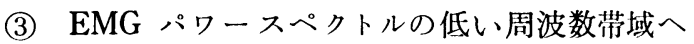

の移動(徐波化)である ${ }^{201}$. 一方, 筋の生理的・生 化学的適応の客観的指標としては, $\dot{\mathrm{V}} \mathrm{O}_{2}$, 血中乳 酸レベル，グリコーゲン，クレアチン，クレアチ ン燐酸，ATP などの変化を測定し，筋疲労の指 標としての研究が進められてきた ${ }^{1,6,30,31)}$.

本研究では, この筋収縮を電気的活動としてと ら充, 実際に筋疲労を起こさせ, 筇疲労の定義に したがい，客観的評価を行い，筇力トレーニング を疲労困価まで行わずに効率良いトレーニングが できないものかを模枽することを目的としたもの である。

\section{II. 方 法}

汎用パソコン ( NEC 製. PC $9801 \mathrm{VX})$ を用いた 高精度筇電位解析システム (キッセイコムテック 製 BIMUTAS Ver. 2. 1)により, 等尺性収縮時の 示指伸笳の疲労度を解析した。実験装置のブロッ クダイヤグラムを図1に示した。また，被験者に は健常成人男子 8 名 $(19 \sim 42$ 歳)を用い, 示指伸筋 の負荷として，手関節および示指以外の指を熱可 塑性材料 (東京衛材製 New polycast) で固定し, 遠位指節間関節に一致した位置に, $300,600 \mathrm{~g}$ の 重鍾を吊り下げた。重鍾は約 30 秒以上 1 分 30 秒以

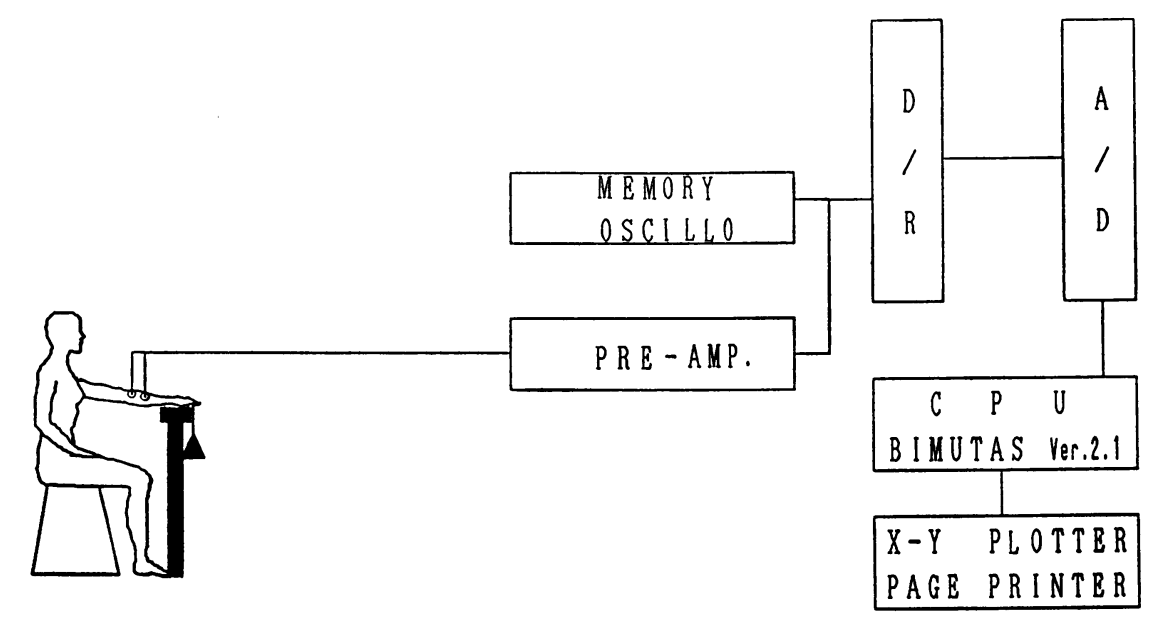

Fig. 1. Block diagram of experiment. 
内にそれが落下するまでのものを選び，その間の 筋放電位を生体用前置増幅器 (日本光電製 AVB10）を介してメモリーオシロスコープ（日本光電 製 VC-10) で観察した。筋電図は, データ・レコ ーダ（ミネベフ製 RCD 728）に入力し，テープス

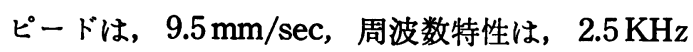
で保存した. その後, 同時サンプリング機能付入 力装置と $\mathrm{A} / \mathrm{D}$ コンバータ (キッセイコムテック 製 KC-210) を介して，サンプリング・レート $1 \mathrm{KHz}$ でパーソナルコンピューターに取り込ん だ. 表面筋電図の導出には，ゲル状の皮膚研磨剤 で前処理した後, 直径 $1.5 \mathrm{~cm}$ の銀／塩化銀電極 を示指伸筇筋腹中央の皮居表面上に貼り付けた. 皮膚インピーダンスは, 皮膚インピーダンス測定 装㡹 (日本電気三栄製特注)によって $20 \sim 500 \mathrm{~Hz}$ の範囲で可及的に $2 \mathrm{~K} \Omega$ 以下になるよう処置した. 筋電計の周波数特性は $0.08 \sim 3000 \mathrm{~Hz}$ とし, 解析 時には $10 \sim 500 \mathrm{~Hz}$ の band pass filter をかけた。 負荷開始から重鍾落下までの時間を10等分し，そ の10等分の始めの $1000 \mathrm{~ms}$ ずつをサンプリング
し，それを解析用データとして保存した（S1〜 S 10).ささらに, 各サンプルごとに筋放電位の積分 処理を行い, 周波数パワー・スペクトルの mean power frequency (MePF) と median power frequency (MdPF) を算出した.

算出方法は，下記の方法でおこなった。

MEAN 周波数 (f mean)

$$
f \text { mean }=\frac{\int_{0}^{f} f \cdot P \times \times(f) d f}{\int_{0}^{f} P \times \times(f) d f}
$$

MEDIAN 周波数

$$
\begin{aligned}
& \int_{0}^{\mathrm{fmed}} \mathrm{P} \times \times(\mathrm{f}) \mathrm{df}=\int_{\mathrm{fmed}}^{\infty} \mathrm{P} \times \times(\mathrm{f}) \mathrm{df} \\
& \text { fmed ; median frequency } \\
& \mathrm{P} \times \times(\mathrm{f}) \text {; パワー } \\
& \times \quad \text {; square }
\end{aligned}
$$
III. 結
果

被験者 1 名から導出した筋電図のデータを図 2

Raw Data Sampling Rate: $1.000 \mathrm{KHz} \quad 29521.00 \mathrm{msec}$

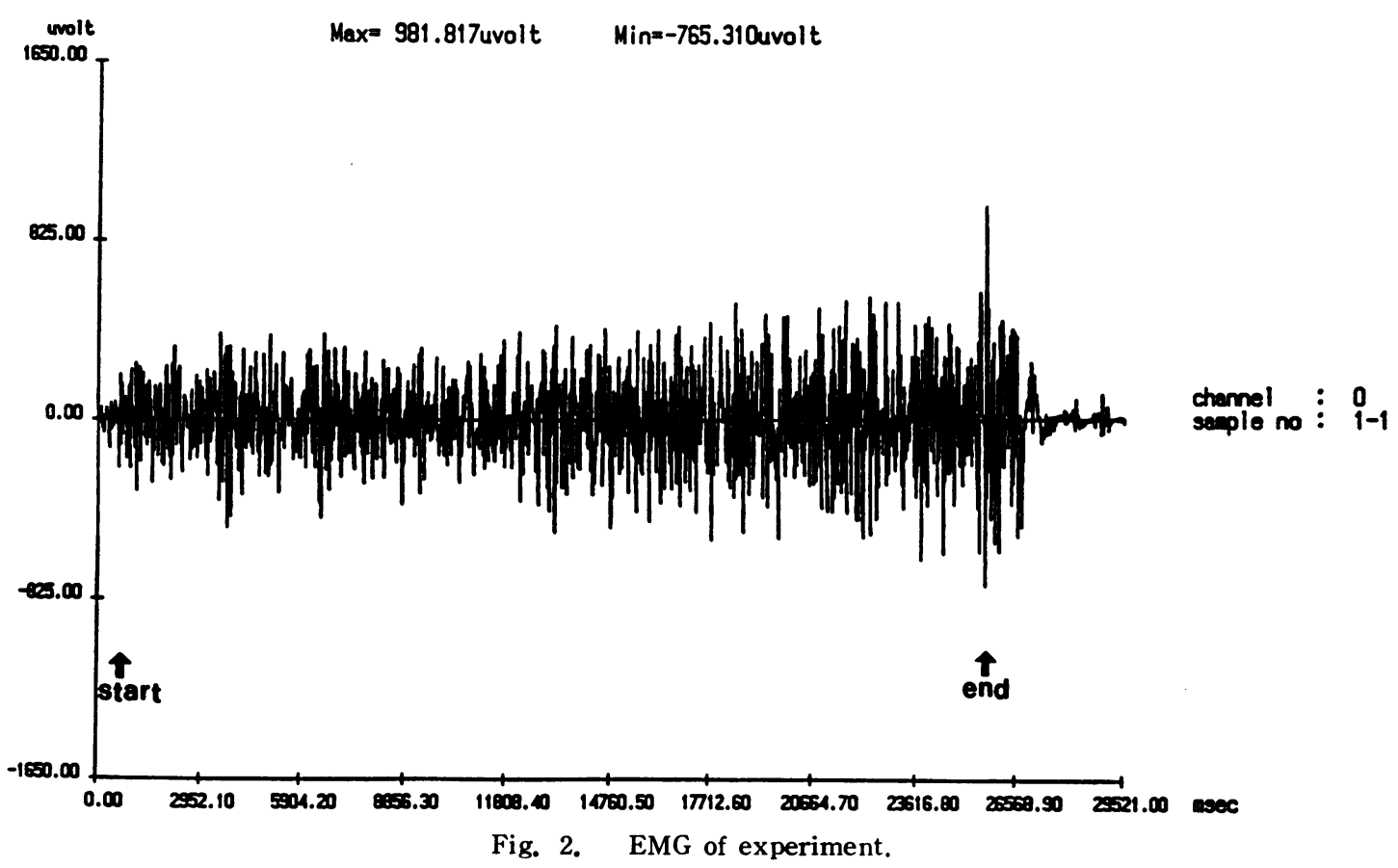


に示した．重錘を吊りさげ，それが落下するまで の時間は被験者によって異なったが，27〜81 sec の間にあった．縦軸は電圧值 $(\mu \mathrm{v})$ を示し横軸は 時間を $\mathrm{ms}$ で表示している. 矢印, 左側が重錘を 吊りさげた時点であり，右側は重鍾が落下した時 間を示している.負荷開始から時間の経過ととも に筋放電位の振幅は上昇していき，重鍾落下直後
で最大になり，落下とともに急速減少した．

図 3 は, 筋電図のデータを高速 フーリエ変換 し，周波数解析を行なったものである. 緹軸は， $\mu \mathrm{V}^{2} / \mathrm{Hz}$ ，横軸は $\mathrm{Hz}$ をあらわしている。 また， 右横の表示は，重鍾落下までの時間を10等分し， それぞれの始めの $1000 \mathrm{~ms}$ ずつとったサンプルナ

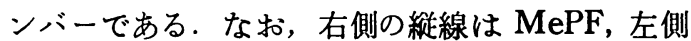

Power Spectrum

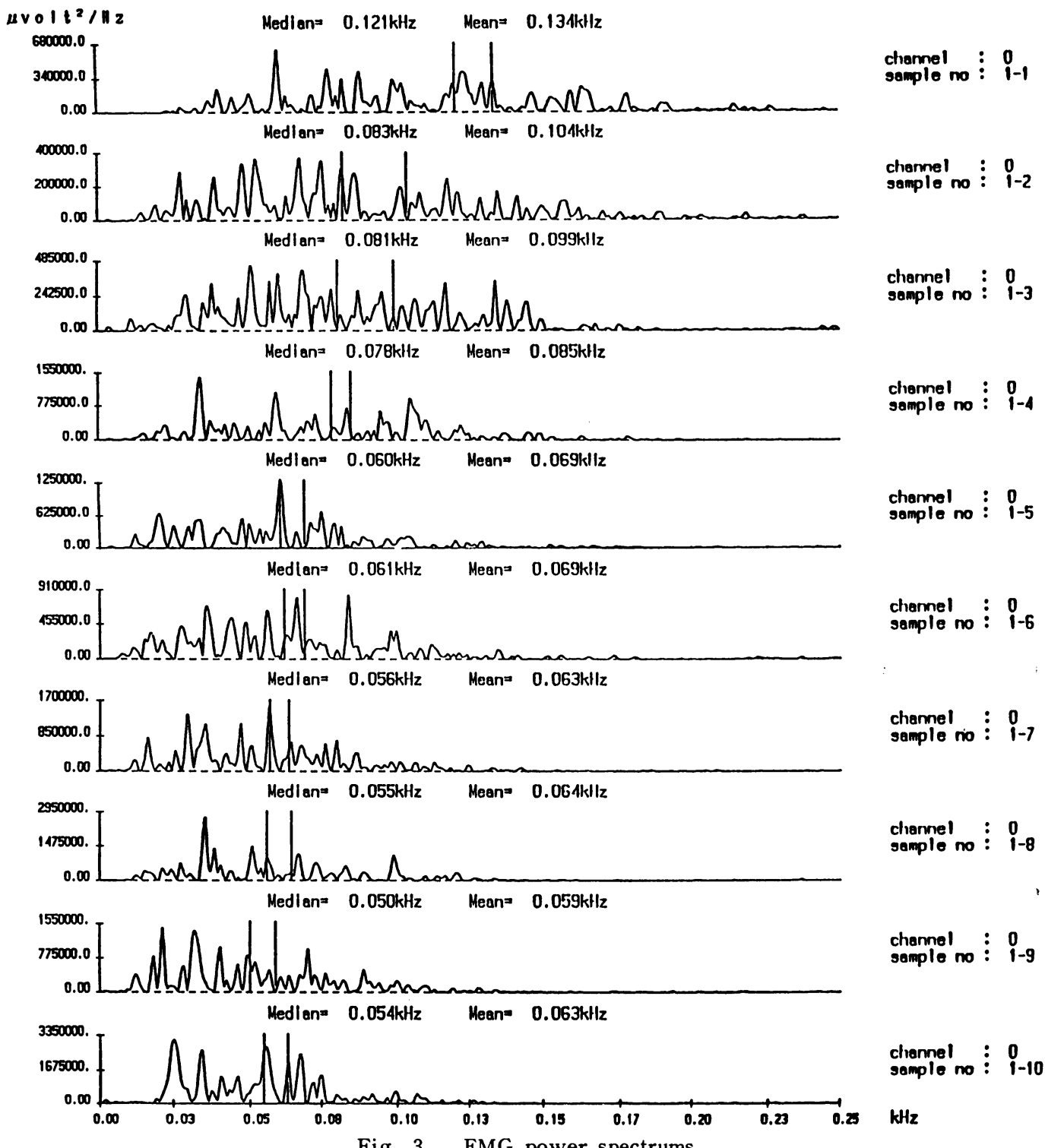

Fig. 3. EMG power spectrums. 
の縦線は MdPF を表わしている. 周波数成分が 左側にシフトし, MePF, MdPF も左側により, 徐波化の傾向を示した.

因 4 は，それを 2 次データとして保存し積分し たものである.左側の縦軸は積分值を $\mu \mathrm{V}$ で表し， 右側の記載はサンプルナンバー，横軸は時間を示 している．負荷をかけてからの積分值は時間の経
過とともに增加していた。

図 5 は, 被験者 8 名に打ける各サンプルごとの 積分值の平均を表したものである，值は，時間と ともに上昇傾向を示しているが，標準偏差が大き くなった。

図 6 は, 被験者 1 名の $\mathrm{MePF}$ と $\mathrm{MdPF}$ の各サ ンプリングナンバーをそれぞれ移動 3 点平均して

Integral Process $\quad 1000.000 \mathrm{msec}$

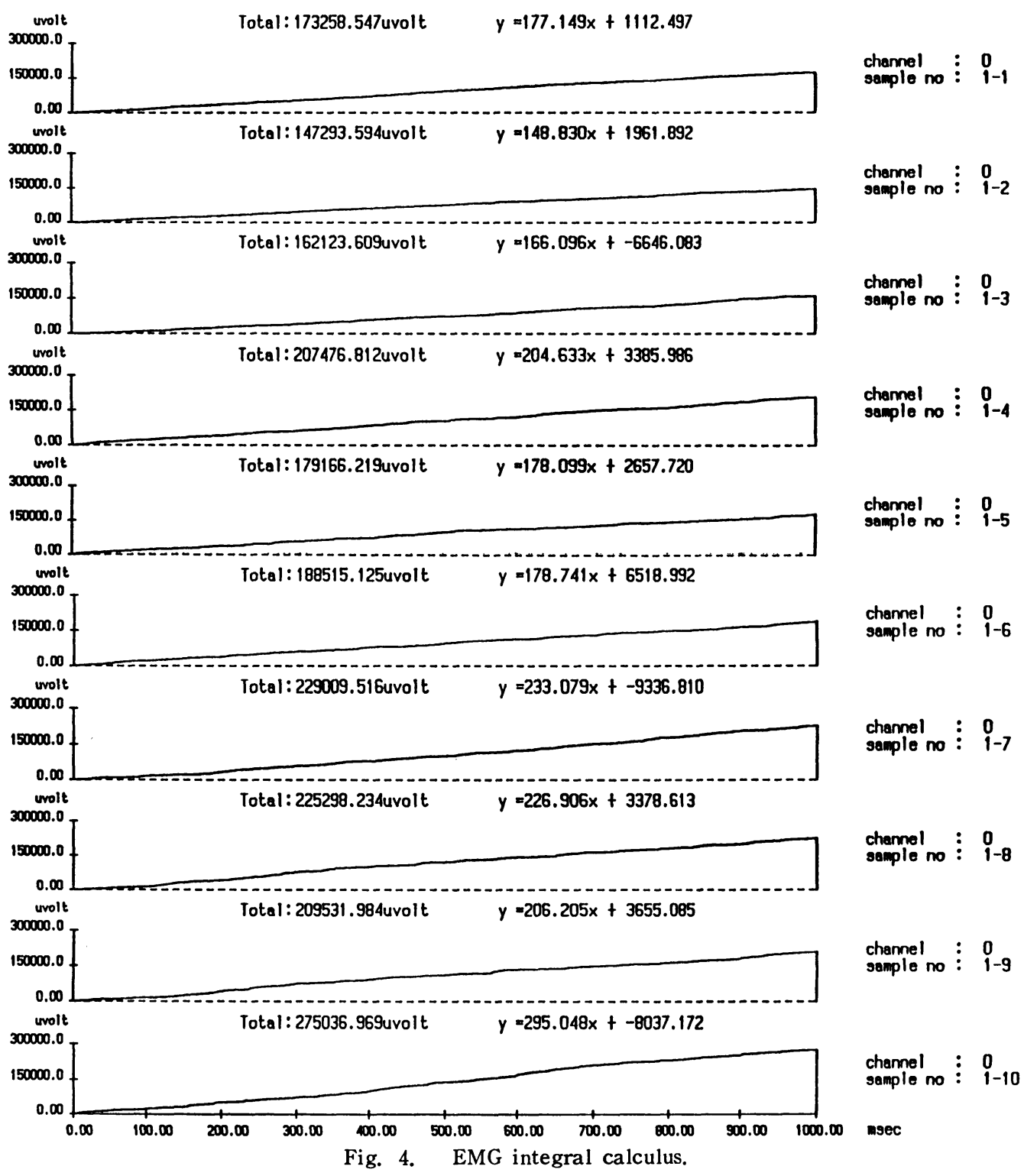




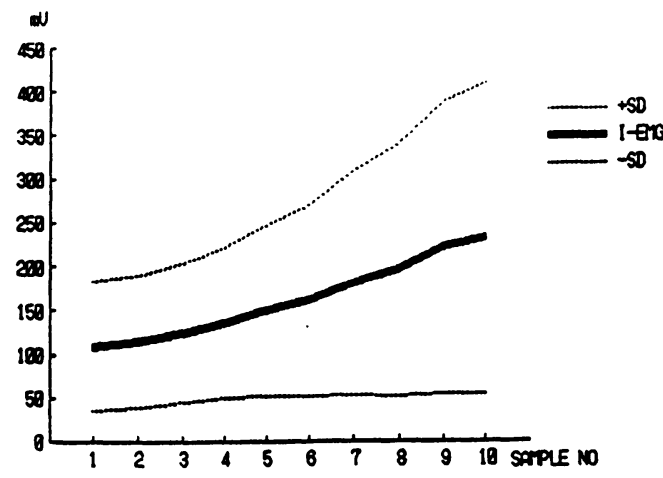

Fig. 5. Time course for integrated areas of 10 EMG divisions.

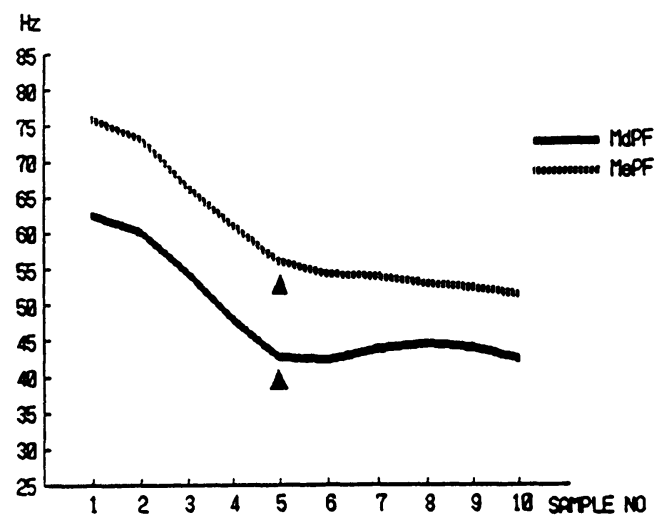

Fig. 6. MePF and MdPF with time of a example (subject : male 20 years).

$\Delta$ : A break point.

表したものである. MePF, MdPF ともに偏曲点 (Break point)が確認された ${ }^{13)}$. さらに, 被験者 8 名を平均してまとめた $\mathrm{MePF}$ と $\mathrm{MdPF}$ が図 7，8である.上下の点線は標準偏差を表してい る. 図 7 からは偏曲点は明確でなかったが，図 8 の MdPF ではこの偏曲点が確認された。

\section{IV. 考察}

被験者 1 名から導出した筋電図のデータを図 2 に示したが，その筋電図のデータを高速フーリェ 変換し, 筋放電スペクトル波形によって周波数解 析を行なったものが図 3 である．筋電図の解析方 法は, 笳線維タイプについての報告 ${ }^{32,33)}$ から筋放 電スペクトル波形についての報告 ${ }^{14)}$ ，さらにそれ らを応用した報告も見られ7,19,25)，その用途は多

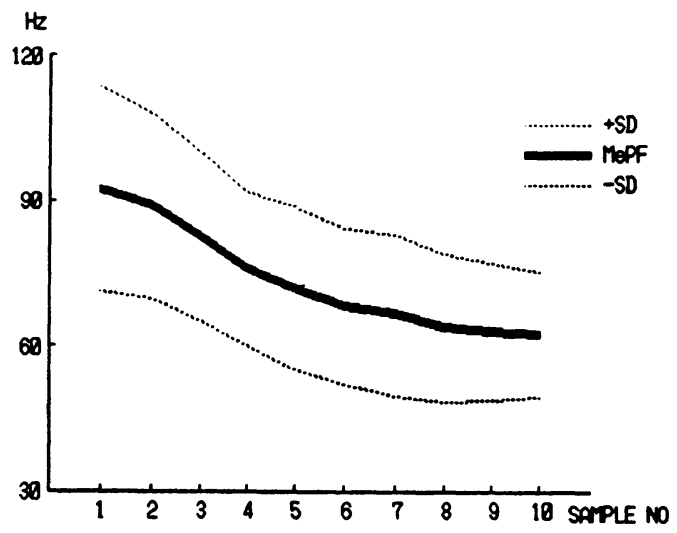

Fig. 7. Averaged time course of MePF for 8 subjects.

A break point which appears in individual curve disappears in the averaged time course.

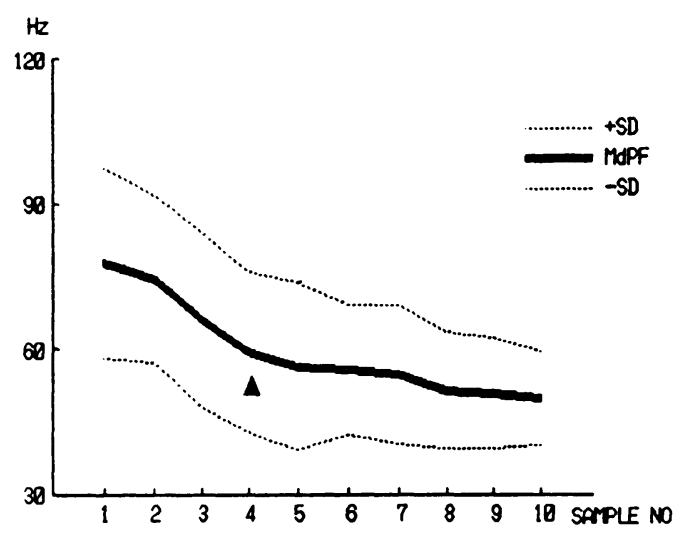

Fig. 8. Averaged time course of MdPF with time for 8 subjects.

$\Delta$ : A break point.

様化されてきている。

永田 ${ }^{211}$ は筋放電のパワー・スペクトルにより上 腕二頭笳の疲労を解析しているが, 疲労するに従 いスペクトルは徐波（ゆっくりとした周波数成 分）化の傾向を強く示している. そして疲労前後 の筋電スペクトルの MPF (MePF) をとってみる と統計的に有意な变動を示した.すなわち，疲労 前の平均パワー周波数は $110 \mathrm{~Hz}$ を示したが疲労 後は $54 \mathrm{~Hz}$ を示し, 疲労後の二つの值を比較する と湿著な堿少が認められ，こうした恋動はその筋 を構成している筋線維タイプに左右される, と報 告している. 
本実験より周波数解析した筋電位の $\mathrm{MePF}$ (mean power frequency) と MdPF (median power frequency)に注目してみると，重錘を吊り下げ て最初の S1 では, MePF は $134 \mathrm{~Hz}$ を示し， MdPF では $121 \mathrm{~Hz}$ を示していた，しかし，時間 が経過するとともに $\mathrm{MePF}, \mathrm{MdPF}$ の周波数成 分はともに左側にシフトし徐波化の傾向が見受け られ S 10 では, MePF は $63 \mathrm{~Hz}, \mathrm{MdPF}$ は $54 \mathrm{~Hz}$ を示し，周波数は減少した。これは，前述の永田 の疲労前と疲労後の值とほぼ一致した結果となっ た.

疲労に関する報告としては, 1890年 Mosso ${ }^{18)}$ のエルゴグラフ（筋作業記録器）から得られた疲 労曲線に代表されるが，この疲労曲線が $\mathrm{MePF}$ と MdPF の曲線と非常に酷似していることに気 付く、またこの結果を1967年に猪飼と矢部 ${ }^{10,12)} ら$ が追試実験し，意志による最大筇発生張力よりも 電気刺激による最大筋発生張力のほうが高い值を 示すことから, 疲労曲線は中枢性のものだけでは なく末梢性の問題も無視できない，といら報告も あり現時点では中枢性と末梢性双方の要素を考虑 せざるを得ないるのと考兄られる。

周波数成分を積分した図 4 では，S1 の值は， $173 \mathrm{mV} \cdot \mathrm{ms}$ であったのに対し, $\mathrm{S} 10$ では $275 \mathrm{mV}$. $\mathrm{ms}$ と增加した。このことから筋疲労が起ってい るものと考えられる。ささらに，全ての被験者にお ける各サンプルごとの積分值を平均し，それを移 動 3 点平均したものが図 5 である．標準偏差に多 少のばらつきはあったものの，時間の経過ととも に積分値は増加しており，ここでも筇疲労を起こ している過程を間接的に考察することができる. 以上のことから筋電位の疲労の定義である, 同一 張力下での積分値の增加, 周波数パワースペクト ルの徐波化があげられ，示指伸筋における局所性 筋疲労の発生が観察できたと考える.

図6は, S1 から S10 の各サンプルごとの $\mathrm{MePF}, \mathrm{MdPF}$ をそれぞれ移動 3 点平均したグラ フである. MePF は S 5.4, MdPF は S4.9 のと ころで, 偏曲点 (Break point) ${ }^{131}$ が確認された。 しかし，この点はサンプルナンバーの非連続性と いった観点から，小数点を四捨五入し，いずれも
偏曲点は S 5 とした。他の被験者においても S4 からS 6 の間で偏曲点が確認された。これより， 時間の経過とともに偏曲点までは急速に下降して いるが，偏曲点を過ぎると緩徐な下降かまたはプ ラトーをたどっていることがわかる.さらに，全 ての被験者に打ける各サンプルごとの $\mathrm{MePF}$ と $\mathrm{MdPF}$ を平均しそれぞれ移動 3 点平均した $\mathrm{MePF}$ では, 偏曲点は見出せなかったものの， MdPF では S 5 のところに偏曲点が見出されて いる. $\mathrm{MePF}$ は, パワースペクトルの面積を平均 した値で運動単位参加様式を評価したものとして 用いられているが ${ }^{14,27)}, \mathrm{MdPF}$ はその中央值を示 している(前述の算出式参照). MePF はパワース ペクトル分布の裾がのびている方に引き指られる 傾向があり, 最頻值は分布のすみの方に行くこと がある.これに対し，MdPF の位置は分布形の動 きに対しても比較的安定していることから ${ }^{291}$, $\mathrm{MePF}$ と MdPF の偏曲点に違いが出てきたもの と思われる.

以上のことから, 筇電位解析による周波数パワ 一の変動様式は偏曲点を境に変化しており，この 点をどのように解釈するかが今後の課題であろ ら.また偏曲点以降は下降傾向から緩やかにな り, 疲労が蓄積され, やがて疲労困䣏となり重錘 が落下するものと考えられる，実験中に打ける被 験者の生理的状態について述べると, 偏曲点を過 ぎたあたりから顔が強ばり，腕にふるえが出現 し，続いて指が下がって重錘の落下に至ってい る.このような状況を踏まえて，筋力トレーニン グを考えていくと，単に生理的限界までおい込む のではなく，偏曲点を過ぎたあたりでトレーニン グを中止することにより，著しい疲労を残すこと 無く，効率の良いトレーニング効果があげられる 可能性が示唆される. 今後の課題としては, 負荷 の方法を工夫し, 四肢体幹の各筋群で同様の検索 を試みるつもりである.

\section{v. よ め}

沉用パソコンを用いた高精度筋電位解析システ ム (BIMUTAS Ver. 2.1) により，等尺性収縮時の 示指伸筋の筋放電位を解析した，被験者には健常 
成人男子 8 名 $(19 \sim 42$ 歳)を用い，示指伸筋の負荷 として，遠位指節間関節に $300 ， 600 \mathrm{~g}$ の重鏵を 吊り下げ，それが落下するまでの筋放電位を記録 した．負荷開始から重鍾落下までの時間を10等分 (S 1 S 10) し，A/D 変換の後それぞれ $1000 \mathrm{~ms}$ ずつサンプリングした. 各サンプルごとに周波数 パワースペクトルの MePF, MdPFを算出した. その結果；

1) MePF と MdPF は時間の経過とともに全 例において著明な徐波化傾向を示した.

2）筇放電位における積分值は時間とともに顕 著な増加を示した。

3) S1〜S10のサンプルごとの MePF, MdPF を移動 3 点平均処理するとそのグラフの中心附近 に偏曲点を確認できた。

以上のことから，筋電位周波数解析から見た局 所筋疲労の偏曲点, 特に MpPF の偏曲点は筋疲 労の客観的指標として有用性があるものと考えら れた。

この論文は，1989年第44回体力医学会で発表したもの である.

(受付 平成 3 年 6 月 14 日)

\section{Refernces}

1) Chwalbinska-Moneta, J., Robergs, R. A., Costill, D. L. and Fink, W. J. (1989): Threshold for muscle lactate accumulation during progressive exercise. J. Appl. Physiol., 66(6), 2710-2716.

2) DeLorme, T. L. and Watkins, A. L. (1948) : Technics of progressive resistance exercise. Arch. Physiol. Med., 29, 263-273.

3) Eccles, J. C. (1948) : Conduction and synapatic transmission in nervous system. Ann. Rev. Phys. iol., 10, 93-116.

4) Fatt, P. and Katz, B. (1951): An analysis of the endplate potential recorded with an intracellular electrode. J. Physiol. 115, 320-370.

5) Fex, J. and Krakau, C. E. T. (1958) : Frequency analysis of the Piper rhythm, Acta Psychiat. Neurol. Scandinav., 33, 54-68.

6) Fitts, R. H. and John, O. H. (1976) : Lactate and contractile force in frog muscle during development of fatigue and recovery. Am. J. Physiol., 231, 430-433.

7) Hagbarth, K. E., Hagglund, J. V., Wallin, E. U. and Young, R. R. (1981): Grouped spindle and electromyographic responses to abrupt wrist extension movements in man. J. Physiol (Lond). 312, 81-96.

8) ヘティンガー, Th. (1970)：アイソメトッリクトレ ーニング, 初版, 筋カトレーニングの理論と実際. 大修館書店, 東京, 79-139.

9) Hunt, C. C. and Kuffler, S. W. (1950) : Pharmacology of neuromuscular junction. J. Pharmacol. Rev., 2, 96-120.

10) 猪飼道夫 (1970): 生理学体系 $N$. 医学書院, 東京, 721-780, 937-975.

11) Ikai, M. and Fukunaga, T. (1970): A study on training effect on strength per unit crosssectional area of muscle of ultrasonic measurement. Int-ZAngew-Physiol., 28(3), 173-180.

12）猪飼道夫, 矢部京之助 (1967) : 筇力と疲労の研究. 体育の科学, 17, 108-113, 166-172.

13) Jones, R. H. and Molitoris, B. A. (1984) : A statistical method for determining the breakpoint of two lines. Analytical biochemistry., 141, 287-290.

14) Komi, P. V. and Tesch, P.(1979): EMG frequency spectrum, muscle structure and fatigue during dynamic contractions in man. Eur. J. Appl. Physiol., 42, 41-50.

15) Kwatny, E. Thomas, D. H. and Kwatny, J. G. (1970) : An application of signal processing techniques to the study of myoelectric signals. IEEE Transactions on Bio-medical Engng., 17, 303-313.

16) Moritani, T. and de Vries, H. A.(1978) : Reexamination of the relationship between the surface integrated electromyogram (IEMG) and force of isometric contraction. Am. J. Phy. Med., 57, 263277.

17) Moritani, T. and de Vries, H. A. (1979): Neural factors versus hypertrophy in the time course of muscle strength gain. Am. J. Phy. Med., 58, 115130.

18) Mosso, A. (1890): Untersuchungen an Muskeln des Menschen. Arch. f. Physiol., 89-168. 
19) Nagata, A. (1982) : EMG power spectra during various levels of isometric contraction and fatigue. Yokohama. Med. Bull., 33, 1, 49-74.

20) 永田 晟(1983)：からだ・運動の科学. 朝倉書店, 東京, 15-57.

21）永田 晟 (1984) : 筋と筋力の科学. 不昧堂, 東京, 129-176.

22）永田 晟, 室 增夫, 北本 拓(1975)：笳収縮時の 放電周波数特性(第 1 報), 等尺性表面筋電図の相関 関数・フーリェ解析. 体力科学, 24, 111-117.

23）奥村修三(1957)：表面筋電図の周波数スペクトルに 関する基礎的研究. 岡山医学雑誌, 69, 401-411.

24) Person, R. S. and Mishin, L. N. (1964) : Auto and cross-correlation analysis of the electrical activity of muscles, Med. and Biol. Eng., 2, 155-159.

25) Petorfsky, J. S. (1979) : Frequency and amplitude analysis of the EMG during exercise on the bicycle ergometer. J. Appl. Physiol., 41, 1-15.

26) Piper, H. (1912) : Elektorophysiologie menschlicher Muskeln. Springer Verlag, Berlin.

27）鲛島宗弘 (1973) : 表面筋電図のスペクトル解析. 臨 床脳波，15，375-383.

28) Scott. R. N.(1967) : Myo-electric energy spectra.,
Med. and Biol. Eng., 5, 303-305.

29）芝袥順，渡辺 洋，石塚智一(1984)：統計用語辞 典. 新曜社, 東京, 170-171.

30) Spande, J. I. and Schottelius, B. A.(1970) : Chemical basis of fatigue in isolated mouse soleus muscle. Am. J. Physiol., 219, 1490-1495.

31) Talmadge, R. J., John, I. S. and Silverman, H. (1989): Glycogen synthesis from lactate in a chronically active muscle. J. Appl. Physiol., 66 (5), 2231-2238.

32) Tesch, P., Sjodin, B., Thorstensson, A. and Karlsson, J. (1978) : Muscle fatigue and its relation to lactate accumulation and $\mathrm{LDH}$ activity in man. Acta. Physiol. Scand., 103, 413-420.

33) Thorstensson, A. and Karlsson, J. (1976) : Fatigability and fiber composition of human skeletal muscle. Acta. Physiol. Scand., 98, 318-322.

34）時実利彦, 津山直一(1952)：彷電図の臨床. 協同医 書, 東京, 68-81.

35) Walton, J. N. (1952) : The electoromyogram in myopathy, Analysis with the audiofrequency spectrometer. Neurosurg. Psychiat., 15, 219-226. 